$\square$ 원 저 $\square$

\title{
폐암환자의 $\mathrm{T}$ 임파구 아형분석 ( I )
}

\author{
충남대학교 의과대학 내과학교실

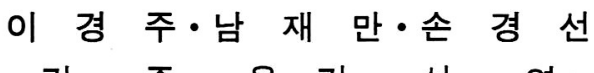 \\ 김 주 옥・김 선 영
}

$=$ Abstract $=$

\section{T-Cell Subset in Patients with Lung Cancer(I)}

Kyoung Joo Rhee, M.D., Jae Man Nam, M.D., Kyung Sun Son, M.D.

Ju Ock Kim, M.D., and Sun Young Kim, M.D.

Department of Internal Medicine, College of Medicine, Chung Nam National University

The authors studied T-lymphocyte subset and delayed skin hypersensitivity in 48 patients with bronchogenic carcinoma.

1) The percentage of lymphocyte and total lymphocyte counts significantly decreased in patient group $(\mathrm{P}<0.002)$.

2) Percent of $\mathrm{OKT}^{+} \mathrm{T}$-lymphocyte decreased and $\mathrm{OKT} 4^{+} / \mathrm{OKT}^{+}$ratio increased in patient group (especially squamous cell lung cancer and adenocarcinoma) $(\mathrm{P}<0.05)$.

3) Percent of $\mathrm{OKT} 8^{+}$cells significantly decreased in stage III but not in stage I \& II of nonsmall cell lung cancer $(\mathrm{P}<0.05)$.

4) Numbers and total scores of positive reactions in CMI multitest significantly decreased in patient group $(\mathrm{P}<0.005)$

Decreased cellular immune function in patients with lung cancer may be associated with progression of disease and risk of opportunistic infection.

Although it is not clear whether altered immune function occurs only as a results of advanced disease or develops in certain patients predisposing them to further spread of tumor, it is important to assess cellular immune function in lung cancer patients.

\section{서 론}

폐암은 내과적 또는 외과적 치로에 잘 반응하지 않는 흔한 악성종양으로 종종 세포성 면역 (Cell-Mediated Immunity)의 감소가 보고되었다 ${ }^{129}$. 면역기능의 변화 가 종양의 유발인자가 되는지 또는 종양에 의해서 면역 기능의 저하가 초래되는지는 알 수 없으나, 면역기능의 변화는 폐암의 발생과 진행에 중요한 역할을 할 것으로 추측되어 왔다. 최근의 연구는 폐암환자에서 면역기능의 감소가 종양의 생물학적 영향, 질환의 범위, 영양불량등 과 관계있다는 것과 폐암환자에서 임파구아형의 변화가
있음을 보고하였닥. 종양의 발생 및 전파에 대한 숙주 의 정확한 방어기전은 일 수 없지만 폐 및 혈액에서 발 견되는 어떤 종류의 임파구는 암세포를 파괴하는 능력을 가지는 것으로 알려졌고, 최근 자연 살해세포 (NK Cell) 및 Lymphokine Activated Killer Cell 등에 대해서도 많이 연구되고 있다미.

저자들은 48 명의 폐암환자를 대상으로 T읻파구 아형 분석 및 지연형 피부과민반응검사를 시행하여 폐암환자 에서의 세포성 면역상태를 분석하고, 치료에 따른 세포 성 면역상태의 변화를 알아보고자 하였다. 


\section{대상 및 방법}

\section{1. 대 상}

1987년 3월부터 1987년 9월까지 충남대학병원 내과에 입원하여 조직학적으로 확진된 48 명의 폐암환자를 대상 으로 T임파구 아형분석 및 지연형 피부과민반응검사를 시행하였다 (Table 1).

환자군의 연령분포는 34 세부터 76 세까지로 평균 57.8 세였고, 남녀비는 $3.8: 1$ 이었다. 세포형은 편평상피암 27 예, 선암 9예, 소세포암 12예였고, stage는 Limited disease (stage I \& II)가 9예, Extensive disease (Stage III)가 38 예였다.

$\mathrm{T}$ 임파구 아형분석의 정상대조군은 20 세에서 50세 (평 균 $35 \pm 10$ 세)까지의 건강한 남녀 28 명이었고, 지연형 피 부과민반응검사의 정상 대조군은 46세에서 66세(평균 $50 \pm 6$ 세)까지의 건강한 정상남녀 10 명이었다.

\section{2. 방 법}

\section{1) 말초혈액 $\mathrm{T}$ 임파구 아형분석}

(1) 재 료

(1) Ficoll-Hypaque 용액: Histopaque ${ }^{\circledR}-1077$ (Sigma Diagnostics)

(2) Washing medium: phosphate Buffered Saline (PBS), 7.4

(3) Suspension medium: 2 Vol\%의 Bovine Serum Albumin (BSA)을 포함한 PBS, pH 7.4

(4) Mounting medium: 3 Vol\%의 Glycol을 포함한 PBS, pH 7.4

(5) 임파구에 대한 단세포항체 (Monoclonal Antibo$\mathrm{dy})$ : Ortho사의 OKT4, OKT8을 사용하였다. 이들은 Kung등에 의해 만들어진 잡종단세포군항체로 OKT4는 조력 $\mathrm{T}$ 임파구(Helper T lymphocyte)와, OKT8은 억 제 T임파구(Suppressor T Lymphocyte)와 반응한다.

(6) Fluorescence-labeled goat antimouse immunoglobulin: Ortho사의 FITC-GAM시약을 PBS, $\mathrm{pH} 7.4$ 용액으로 20 배 희석하여 사용하였다.

\section{(2) 말초혈액 임파구의 분리}

각 환자군과 정상대조군에서 $10 \mathrm{ml}$ 의 정맥혈을 Heparin 처리한 주사기로 채혈하여 생리적 식염수 $10 \mathrm{ml}$ 를 넣은 시험관에 희석한 후 Ficoll-Hypaque용액이 들
Table 1. Characteristics of Patients

\begin{tabular}{|c|c|c|}
\hline \multicolumn{2}{|c|}{ Characteristics } & \multirow{2}{*}{$\begin{array}{l}\text { Number } \\
57.8 \pm 11.2\end{array}$} \\
\hline Age & & \\
\hline \multirow[t]{2}{*}{ Sex } & Male & 38 \\
\hline & Female & 10 \\
\hline \multicolumn{3}{|c|}{ Pathology } \\
\hline & Squamous cell carcinoma & 27 \\
\hline & Adenocarcinoma & 9 \\
\hline & Small cell carcinoma & 12 \\
\hline \multirow[t]{2}{*}{ Stage } & Limited & 10 \\
\hline & Extensive & 38 \\
\hline
\end{tabular}

어있는 시험 관에 조심스럽게 중첩하여 실온에서 $400 \mathrm{G}$ 로 30 분간 원 침하여 분리된 임파구층을 Pasteur Pipette를 사용하여 채취하였다. 이들 임파구에 PBS $10 \mathrm{ml}$ 를 가 해 $300 \mathrm{G}$ 로 10 분간, $100 \mathrm{G}$ 로 10 분간 원침시켜 세척하였 다. 분리된 임파구는 $2 \%$ PBS-BSA용액으로 최종임파 구수가 $5 \times 10^{6} / \mathrm{ml}$ 가 되도록 조절하였다.

\section{(3) 단세포군 항체를 이용한 T임파구 아형의 정량}

(1) 임파구와 단세포항체 결합 : 시험관에 임파구 부유 액 $200 \mu \mathrm{l}$ 를 분주한 후, $4^{\circ} \mathrm{C}$ 에 저장되어 있던 단세포군 항체 $\mathrm{OKT} 4, \mathrm{OKT} 8$ 을 $5 \mu \mathrm{l}$ 씩 가하였다. 시험관을 흔들 어 세포부유액과 항체를 잘 섞은 다음 10 분마다 한번씩 흔들어 주면서 $4^{\circ} \mathrm{C}$ 저온수조에서 30 분간 작용 (Incubation)시킨후 PBS용액 $2 \mu 1$ 를 가하고 $300 \mathrm{G}$ 로 10 분간 원 침세척하여 부유액을 $100 \mu \mathrm{l}$ 정도 남기고 다시 동일한 방 법으로 세척하여 세포부유액이 $100 \mu 1$ 되게 하였다.

(2) 형광염 색 : 각 시험관에 $1: 20$ 으로 희석한 FITC$\mathrm{GAM} 100 \mu$ 씩을 가한후 $4^{\circ} \mathrm{C}$ 저온수조에서 반응시키고 위와같이 $\mathrm{PBS}$ 로 2회 세척을 하였다.

(3) 검경 및 판독: 세척이 끝난 세포부유액에 mounting medium 1 2방울을 가하여 입자가 뭉치지 않도록 풀어준후 부유액을 Slide에 점적하여 형 광현미경하에서 100 개의 임파구중 OKT4 양성세포, OKT8 양성세포를 세어 그 백분율로 하였다.

\section{2) 지연형 피부과민 반응}

Merieux사에서 고안한 Multi-test $\mathrm{CMI}^{\circledR}$ 를 사용하였 다. 이는 7종의 미생물 추출물(Tetanus, Diphtheria, Streptococcus, Tuberculin, Proteus, Candida, Trichophyton)을 항원으로, Glycerin을 대조군으로 하여 동시에 피내접종할 수 있도록 고안된 키트로, 종래에 사 
용했던 여러 방법들을 표준화했고 쉽고 안전하게 시행할 수 있는 쟝점이 있다.

환자의 전박에 항원을 주입한후 48 시간에 판독하여 피 부경결의 직경이 $2 \mathrm{~mm}$ 이상인 것을 양성으로 하였다. 양 성반응의 수와 직경을 측정하고 이들의 총합 및 양성반 응 한개당의 평균치를 계산하였다.

\section{결 과}

\section{1. 폐암환자의 말초혈액 임파구 및 $\mathrm{T}$ 임파구 아형} 분석 (Table 1)

28 명의 정 상대조군에서 총백혈구수는 $7,345 \pm 1,606 /$ $\mathrm{mm}^{3}$, 임파구 백분율은 $37.4 \pm 7.3 \%$, 총 임파구수는 $2,675 \pm 456 / \mathrm{mm}^{3}$ 였고, OKT4 양성임파구의 백분율은 $43.3 \pm 8.9 \%, \quad$ OKT8 양성임파구의 백분율은 $29.7 \pm$ $7.7 \%, \mathrm{OKT} 4$ 양성세포와 $\mathrm{OKT} 8$ 양성세포의 비 (OKT4 $+/ \mathrm{OKT}^{+}{ }^{+}$)는 $1.5 \pm 1.5$ 였다.

폐암환자 34 명에서 총백혈구수는 $9,235 \pm 4,111 / \mathrm{mm}^{3}$ 였고, 임파구 백분율은 $22.8 \pm 8.5 \%$ 로 정상대조군에 비 해 유의하게 감소하였으며 $(\mathrm{P}<0.02)$, 총임파구수도 $1,918 \pm 704 / \mathrm{mm}^{3}$ 로 유의하게 감소하였다 $(\mathrm{p}<0.02)$ OKT4 양성세포 백분율은 $41.7 \pm 11.8 \%$ 로 감소하는 경향 을 보였고, OKT8 양성세포 백분율은 $23.8 \pm 9.4 \%$ 로 유 의하게 감소하였다 $(\mathrm{P}<0.05)$. $\mathrm{OKT}_{4}^{+} / \mathrm{OKT}^{+} 8^{+}$비는 2.
$2 \pm 1.2$ 로 유의하게 증가하였다 $(\mathrm{P}<0.05)$.

\section{2. 폐암환자에서 세포형태에 따른 $\mathrm{T}$ 임파구 아형분석 (Table 3)}

임파구 백분율은 편평상피암 $20.85 \pm 7.63 \%$, 선암 28 . $4 \pm 8.62 \%$, 소세포암 $24.3 \pm 9.5 \%$ 로 정 상대조군에 비해 유 의하게 감소하였다 $(\mathrm{P}<0.005) . \mathrm{OKT} 4$ 양성세포 백분율 은 편평상피암 $43 \pm 10.7 \%$, 선암 $40 \pm 10.9 \%$, 소세포암 $41 \pm 13.9 \%$ 로 정상대조군과 유의한 차이는 없었다. OKT8 양성 세포 백분율은 편평상피암이 $24.3 \pm 8.1 \%$ 로, 선암이 $20.4 \pm 12.2 \%$ 로 유의하게 감소하였으나 $(\mathrm{P}<0$. $05)$, 소세포암은 $24.8 \pm 7.3 \%$ 로 감소는 하였으나 통계적 의의는 없었다. $\mathrm{OKT} 4^{+} / \mathrm{OKT} 8^{+}$비는 편평상피암이 2. $15 \pm 1.42$, 선암이 $2.75 \pm 0.44$, 소세포암이 $1.83 \pm 0.77$ 로 모두 증가하였으나 선암에서만 통계적 유의성이 있었다 $(\mathrm{P}<0.05)$.

\section{3. 폐암환자의 Stage에 따른 $\mathrm{T}$ 임파구아형 (Table 4)}

임파구 백분율이 비소세포폐암중 Limited disease에 서는 $16.5 \pm 4.0 \%$, Extensive disease에서는 $22.9 \pm 8.3 \%$ 였고, OKT4 양성세포 백분율은 각각 $34.4 \pm 9.9 \%, 43$. $6 \pm 6 \%$ 였다. OKT 8 . 양성세포 백분율은 Limited Disease에서 $28 \pm 15.7 \%$, Extensive disease에서 22.6士

Table 2. Lymphocyte Subset in Lung Cancer

\begin{tabular}{lcccccc}
\hline \hline & $\begin{array}{c}\text { Total WBC } \\
\text { iount }\left(/ \mathrm{mm}^{3}\right)\end{array}$ & $\begin{array}{c}\text { Percent of } \\
\text { lymphocyte }(\%)\end{array}$ & TLC $\left(/ \mathrm{mm}^{3}\right)$ & $\begin{array}{c}\text { OKT4 }^{+} \\
(\%)\end{array}$ & $\begin{array}{c}\text { OKT8 }^{+} \\
(\%)\end{array}$ & $\begin{array}{c}\text { OKT4+/ }_{\text {OKT8+ }} \\
\text { OKT }^{+}\end{array}$ \\
\hline $\begin{array}{l}\text { Controls } \\
(\mathrm{n}=28)\end{array}$ & $7,345 \pm 1,606$ & $37.4 \pm 7.2$ & $2,675 \pm 456$ & $43.3 \pm 8.9$ & $29.7 \pm 7.7$ & $1.5 \pm 1.5$ \\
Patients & $9,235 \pm 4,111$ & $22.8 \pm 8.5^{*}$ & $1,918 \pm 704 *$ & $41.7 \pm 11.8$ & $23.8 \pm 9.4 * *$ & $2.2 \pm 1.2 * *$ \\
\hline
\end{tabular}

$* \mathrm{P}<0.002, * * \mathrm{P} \ll 0.05$ TLC : Total lymphocyte count

Table 3. T Cell Subset in Lung Cancer According to Cell Types

\begin{tabular}{|c|c|c|c|c|}
\hline & $\%$ Iymphocyte & $\mathrm{OKT}_{4}^{+}$ & $\mathrm{OKT}^{+}$ & $\mathrm{OKT}_{4}^{+} / \mathrm{OKT}^{+}$ \\
\hline SC $\quad(n=20)$ & $20.85 \pm 7.63 *$ & $43 \pm 10.7$ & $24.3 \pm 8.1 * *$ & $2.15 \pm 1.42$ \\
\hline$A D \quad(n=5)$ & $28.4 \pm 8.62 *$ & $40.1 \pm 10.9$ & $20.4 \pm 1.2 * *$ & $2.75 \pm 0.44 * *$ \\
\hline $\operatorname{SM}(n=9)$ & $24.3 \pm 9.5^{*}$ & $41 \pm 13.9$ & $24.8 \pm 7.3$ & $1.83 \pm 0.77$ \\
\hline
\end{tabular}

SC : squamous cell carcinoma, AD : adenocarcinoma, SM : small cell carcinoma

$* \mathrm{P}<0.005, * * \mathrm{P}<0.05$ 
Table 4. T-Cell Subset According to Stage

\begin{tabular}{lllll}
\hline \hline & \%lymphocyte & OKT4 $^{+}(\%)$ & OKT8 $^{+}(\%)$ & OKT4 $^{+} / \mathrm{OKT}^{+}$ \\
\hline Nonsmall cell & & & & \\
$\quad$ Stage I \& II $(n=5)$ & $16.5 \pm 4.0$ & $34.4 \pm 9.9$ & $28 \pm 15.7$ & $2.26 \pm 0.98$ \\
$\quad$ Stage III $(n=29)$ & $22.9 \pm 8.3$ & $43.6 \pm 6$ & $22.6 \pm 7.7 *$ & $2.29 \pm 1.33^{*} *$ \\
Small cell & & & & \\
$\quad$ Limited $(n=2)$ & $33 \pm 6.6$ & $27.5 \pm 9.2$ & $24 \pm 4.2$ & $1.19 \pm 0.59$ \\
$\quad$ Extensive $(n=7)$. & $20 \pm 7.7$ & $45 \pm 12.5$ & $25 \pm 8.3$ & $2.01 \pm 0.74$ \\
\hline
\end{tabular}

$* \mathrm{P}<0.05, * * \mathrm{P}<0.05$

Table 5. Results of CMI Multitest

\begin{tabular}{llcc}
\hline \hline & $\begin{array}{l}\text { No. of } \\
\text { positive } \\
\text { reaction }\end{array}$ & $\begin{array}{c}\text { Total score } \\
(\mathrm{mm})\end{array}$ & $\begin{array}{l}\text { Average } \\
\text { score } \\
(\mathrm{mm})\end{array}$ \\
\hline $\begin{array}{l}\text { Control } \\
(\mathrm{n}=10)\end{array}$ & $4.8 \pm 1.5$ & $23.3 \pm 11.6$ & $4.6 \pm 1.3$ \\
$\begin{array}{l}\text { Patient } \\
(\mathrm{n}=29)\end{array}$ & $1.8 \pm 1.1^{*}$ & $12.8 \pm 7.7^{*}$ & $4.3 \pm 1.6$ \\
\hline
\end{tabular}

$* \mathrm{P}$ value $<0.005$

Table 6. T-Cell Subset After Chemotherapy

\begin{tabular}{llll}
\hline \hline & Initial & $\begin{array}{l}\text { After } \\
\text { treatment } \\
(n=8)\end{array}$ & P-value \\
\hline OKT4 $^{+}(\%)$ & $41.7 \pm 11.8$ & $44.5 \pm 8.5$ & NS \\
OKT $^{+}(\%)$ & $23.8 \pm 94$ & $23.3 \pm 5.2$ & NS \\
\hline
\end{tabular}

NS : Not significant

$7.7 \%$ 였고, $\mathrm{OKT}_{4}^{+} / \mathrm{OKT}^{+}$비는 각각 $2.26 \pm 0.98,2$. $29 \pm 1.33$ 이 였다. 각 경 우에 서 Limited disease 와 Extensive disease간에 통계적 유의 성은 없었고 Extensive disease에서만 정상대조군에 비해 유의한 $\mathrm{OKT} 8$ 양성세포 백분율의 감소, $\mathrm{OKT}^{+} / \mathrm{OKT}^{+}$비의 증가를 보였다.

소세포암의 경우 Limited Disease와 Extensive disease에서 임파구 백분율은 각각 $33 \pm 6.0 \%, 20 \pm 7.7 \%$, $\mathrm{OKT} 4$ 양성세포 백분율은 각각 $27.5 \pm 9.2 \%, 45.7 \pm 12.5$ $\%$ 였고, $\mathrm{OKT} 8$ 양성세포 백분율은 각각 $24 \pm 4.2 \%, 25 \pm$ $8.3 \%$ 였으며, $\mathrm{OKT}^{+} / \mathrm{OKT}^{-}$비는 각각 $1.19 \pm 0.59$, $2.01 \pm 0.74$ 였다. 각경우에서 Limited disease와 Extensive disease 간에 통계적 유의성은 없었다.
Table 7. CMI Multi-Test After Chemotherapy

\begin{tabular}{lllc}
\hline \hline & Initial & $\begin{array}{l}\text { After } \\
\text { Tx }(n=6)\end{array}$ & P-value \\
\hline Number & $1.8 \pm 1.1$ & $2.3 \pm 1.5$ & NS \\
$\begin{array}{l}\text { Total score }(\mathrm{mm}) \\
\text { Average score } \\
\text { (mm) }\end{array}$ & $1.28 \pm 7.7$ & $9.5 \pm 6.5$ & NS \\
\hline
\end{tabular}

NS : Not significant

\section{4. 폐암환자에서 지연형 피부과민 반응(Table 5)}

정상대조군에서 평균 양성반응수는 $4.8 \pm 1.5$ 개, 직경 의 평균총합은 $23 \pm 11.6 \mathrm{~mm}$, 평균 직경은 $4.6 \pm 1.3 \mathrm{~mm}$ 였으며 무반응(Anergy)은 관찰되지 않았다.

폐암환자에서 평균 양성반응수와 직경의 평균총합은 각각 $1.8 \pm 1.1$ 개, $12.8 \pm 7.7 \mathrm{~mm}$ 로 정상대조군에 비해서 유의하게 낮았고 $(\mathrm{P}<0.005)$ 무반응으로 관찰되지 않았 다. 환자군의 양성반응의 평균직경은 $4.3 \pm 1.6 \mathrm{~mm}$ 로 정 상 대조군과 차이가 없다.

\section{5. 항암제 투여후 T임파구아형 및 지연형 피부과민 반응의 변화(Table 6,7 )}

항암제 투여후 OKT4 양성세포 백분율은 $44.1 \pm 8.5 \%$ 로, OKT8 양성세포 백분율은 $23.3 \pm 5.2 \%$ 로 치료전에 비해 유의한 변화는 없었다.

항암제 투여후 지연형 피부과민반응의 양성반응수는 $2.3 \pm 1.5$ 개, 직경의 평균총합은 $9.5 \pm 6.5 \mathrm{~mm}$, 평균직경 은 $4.6 \pm 2.2 \mathrm{~mm}$ 로 치료전에 비해 통계적으로 유의한 변 화는 없었다. 


\section{고}

안

폐암환자에서 면역기능을 검사하기 위해서 피부반응검 사, 말초임파구의 mitogen stimulation, 임파구아형등 이 측정되어져 왔고, 이들에서 면역기능의 기능적이며 양 적인 이상이 있음이 알려져 왔다 ${ }^{1}$. 진행된 악성종양에 서 임파구 결핍이 보고되었고, $\mathrm{Yu}$ 등1ㅣ은 Osteogenic Sarcoma의 폐전이에 억제 $\mathrm{T}$ 세포가 중요한 역할을 한다 고 보고하였다. Gross등리은 폐암환자에서 활성 T임파 구가 유의하게 감소하며 또한 기능이 저하되어 있고, 진 단되지 않은 폐의 Coin Lesion이 있는 경우 활성 T임 파구가 감소해 있으면 악성종양을 의심할 수 있다고 보 고하였다. Dellon등 ${ }^{13)}$ 은 폐암의 세포형과 Stage에 따라 서 T임파구의 유의한 차이가 있음을 보고하였다 Paul등 7) 은 흡연환자에서 편평상피암과 비슷한 말초임파구아형을 보이며 이러한 면역조절기능의 변화가 폐암의 발생에 중 요한 역할을 한다고 보고하였다. 임파구아형의 측정은 복 잡하고 환자의 영양상태, 나이, 성별, 투약, 공존하는 다 른 질환, 흡연여부에 따라 많은 변화를 초래할 수 있지 만7) 말초임파구아형의 측정은 폐암환자의 staging과 치 료의 monitoring에 중요한 가치가 있을 것으로 생각된 다 ${ }^{14)}$.

이전에 연구는 폐암환자에서 흡연자에 비해 모든 임파 구의 백분율과 절대치가 감소한다고 하였고, 말초임파구 의 백분율의 감소는 악성 및 양성폐질환의 감별진단에 한 지표로 사용될 수 있다고 하였고, 최근의 연구는 폐암환 자에서 활성 $\mathrm{T}$ 임파구가 증가한다고 하였다 ${ }^{15)}$. 본 연구 에서도 정상대조군에 비해 임파구 백분율 및 총임파구 수 가 유의하게 감소하였다.

$\mathrm{T}$ 임파구가 세포성면역반응을 주로 담당하는 것은 잘 알려져 있다. 특히 조력 $\mathrm{T}$ 임파구는 $\mathrm{B}$ 임파구의 증식 및 항체생성을 촉진하고 억제 $\mathrm{T}$ 임파구의 $\mathrm{B}$ 임파구 억제에 관여하며 기타의 T임파구 및 대식구에도 작용하는 가장 중추적인 면역조절세포로 알려져 있다 ${ }^{16,18)}$.

Ginns등 7,8)은 편평상피암과 중증흡연자에서 OKT4 양 성세포가 감소하여 $\mathrm{OKT}_{4}^{+} / \mathrm{OKT}^{+}$비가 감소한다고 하 였고, 임파절에 전이된 편평상피암에서는 억제 $\mathrm{T}$ 임파구 의 백분율과 수치가 감소한다 하였다. 박등 ${ }^{17)}$ 은 폐암환 자에서 조력 $\mathrm{T}$ 임파구의 유의한 감소를 보고한 반면, Daniel등은 선암의 경우 오히려 OKT8 양성세포의 감소
로 $\mathrm{OKT}_{4}^{+} / \mathrm{OKT}^{+}$비 가 증가한다고 보고하였다. Lewis 등 ${ }^{14)}$ 은 조력 $\mathrm{T}$ 임파구 및 억제 $\mathrm{T}$ 임파구가 진행성 비소 세포폐암, 소세포폐암, 혈청알부민치가 낮은 폐암환자에 서 특히 감소한다 하였다. 본 연구에서는 조력 T임파구 를 의미하는 OKT4 양성세포의 백분율이 유의하지는 않 았으나 감소하는 경향을 보였고, 억제 $\mathrm{T}$ 임파구를 의미 하는 OKT8 양성세포의 백분율은 유의 한 감소를 보였다. 이러한 변화는 제한기 폐암에서는 관찰되지 않았으나 진 행성 비소세포폐암에서 유의 한 감소를 나타내었다. 소세 포폐암에서는 감소하는 경향은 있었으나 통계적 유의성 은 없었다.

박등 ${ }^{17)}$ 은 폐암환자에서 조력 T임파구의 감소로 OKT4 +/OKT8 ${ }^{+}$비의 유의한 감소가 있었으며, 소세포폐암에서 는 전이가 진행될수록 $\mathrm{OKT}^{+} / \mathrm{OKT} 8^{+}$비의 감소가 있었 다고 보고 하였다. 본 연구에서는 OKT8 양성세포의 감 소로 인한 $\mathrm{OKT}_{4}{ }^{+} / \mathrm{OKT}^{+} 8^{+}$비의 증가를 관찰할 수 있었 고 특히 비소세포암중 진행기의 선암에서 유의한 변화를 관찰할 수 있었다.

세포성면역기능을 쉽게 측정할 수 있는 지연형피부과 민반응검사는 항원은 종류 및 양, 판독의 방법에 따라 많 은 차이를 보인다 ${ }^{18)}$. Krant등 ${ }^{19)}$ 은 $\mathrm{DNCB}$ 와 $\mathrm{PPD}$ 를 사 용하여 폐암에서 반응저하를 보고하면서 무반응 (Anergy) 인 경우 생존기간이 단축된다고 하였다. 본 연 구와 동일한 키트를 사용한 송등 ${ }^{19)}$, Cupisol등 ${ }^{20)}$ 에 의하 면 악성종양에서 양성반응의 수, 직경의 총합이 감소되 었으며, 양성반응의 평균직경은 대조군과 유의한 차이가 없다고 보고하였다. 본 연구의 폐암환자에서도 정상대조 군에 비해서 양성반응의 갯수와 직경의 총합이 유의하게 감소하였다. 지연형 피부과민반응은 세포성면역기능의 감소를 확인할 수 있는 유용하고 간편한 지표라고 생각 된다.

일부 환자에서 항암제 사용후 T임파구 아형분석과 지 연형 피부과민반응검사를 하였으나 치료전에 비해서 유 의한 변화는 없었으며, 차후 더 많은 환자를 대상으로 연 구해야 할 것으로 사료된다.

\section{결 론}

저자들은 48 명의 폐암환자를 대상으로 말초혈액 $\mathrm{T}$ 임 파구 아형분석 및 지연형 피부과민반응검사를 시행하여 다음과 같은 결과를 얻었다. 
1) 말초혈액 임파구백분율과 총임파구수는 환자군에 서 $22.8 \pm 8.5 \%, 1,918 \pm 704 / \mathrm{mm}^{3}$ 로 대상군의 $37.4 \pm 7.3$ $\%, 2,675 \pm 456 / \mathrm{mm}^{3}$ 에 비해 유의한 감소를 보였다 $(\mathrm{P}<$ $0.02)$.

2) $\mathrm{OKT} 8$ 양성 세포백분율과 $\mathrm{OKT}_{4}^{+} / \mathrm{OKT}^{+}$비는 환 자군에서 $23.8 \pm 9.4 \%, 2.2 \pm 1.2$ 로 대상군의 $29.7 \pm 7.7 \%$, $1.5 \pm 1.5$ 에 비해 $\mathrm{OKT} 8$ 양성세포의 감소와 $\mathrm{OKT}_{4}^{+} /$ $\mathrm{OKT}^{+}{ }^{+}$비의 증가를 보였다 $(\mathrm{P}<0.05)$.

3) OKT8 양성세포 백분율은 편평상피암에서 $24.3 \pm$ $8.1 \%$, 선암에서 $20.4 \pm 12.2 \%$ 로 유의한 감소가 있었다 $(\mathrm{P}<0.05)$.

4) 비소포폐암에서 OKT8 양성세포 백분율과 OKT4 +/OKT8 ${ }^{+}$비는 Stage III에서 $22.6 \pm 7.7 \%, 2.29 \pm 1.33$ 으 로 Stage I과 II의 $28 \pm 15.7 \%, 2.26 \pm 0.98$ 에 비해서 유 의한 변화가 있었다 $(\mathrm{P}<0.05)$.

5) 지연형 피부과민반응검사는 양성반응의 수, 직경의 총합이 환자군에서 $1.8 \pm 1.1$ 개, $12.8 \pm 7.7 \mathrm{~mm}$ 로 대조군 의 $4.8 \pm 1.5$ 개, $23.3 \pm 11.6$ 에 비해 유의한 감소를 보였다 $(\mathrm{P}<0.05)$.

이상의 결과로 폐암환자에서 조력 T임파구의 감소, 억 제 $\mathrm{T}$ 임파구의 감소, $\mathrm{OKT} 4^{+} / \mathrm{OKT} 8^{+}$비의 증가, 지연형 피부과민반응의 억제가 폐암으로 인한 면역조절기능의 변화로 인한 것으로 사료되며, 또한 이러한 변화가 폐암 의 발생, 진행 및 전이에 관여하리라고 사료된다.

\section{REFERENCES}

1) Dillman RO, Koziol JH, Zavanelli MI, Beauregard JC, Halliburton BI, Glassy MC: Immunoincompetence in cancer patients. Cancer 53:1484, 1984

2) Alsabti EAK: In vivo and in vitro assays of immunocompetence in bronchogenic carcinoma. Oncology 36:171, 1979

3) Catalona WJ, Sample WE, Chretian PB: Lymphocyte reactivity in cancer patients: correlation with tumor histology and clinical stage. Cancer 31:65, 1976

4) Evans DA: Immunology of bronchial carcinoma. Thorax 31:493, 1976

5) Figarella EE, Morillo F, Blanos L, Bianco NE: Failure of cell-mediated effector mechanisms in lung cancer. JNCI, 73:1, 1984
6) Inoue $H$, Ishihara $T$, Kobayashi $K$, Fukai S: Sequential evaluation of DNCB reactivity in patients with primary lung cancer. J Thorac Cardiovas Surg 76: 479, 1978

7) Ginns LC, Goldengeim PD, Miller LG, Burton RC, Gillick L, Colvin RB: T-lymphocyte subsets in smoking and lung cancer. Am Rev Respir Dis 126: 265,1982

8) Ginns LC, Rogol PR, Murphy M: Extent of squamous cancer of the lung correlates with alterations in circulating T cells. Diag Immungol 1:155-61, 1983

9) Ginns LC, Miller LG, Goldenheim PD, Goldstein G, Bria WF: Alterations in immunoregulatory cells in lung cancer and smoking. J Clin Immunol 2:905, 1982

10) Kratikanont $P$, Daniel EB, Chapman BS: Cytotoxic cell function in bronchogenic carcinoma. Chest 91: 90, 1987

11) Yu A, Walts H, Jaffe N, Parkman R: Concomitant presence of tumor-specific cytotoxic and inhibitor lymphocytes in patients with osteogenic sarcoma. N Engl J Med 297:121, 1977

12) Gross RI, Latty A, Williams EA: Abnormal spontaneous rosette formation and rosette inhibition in lung cancer. N Engl J Med 292:439, 1975

13) Dellon AC, Potvin C, Chretien PB: Thymus dependent lymphocyte levels in bronchogenic carcinoma. Cancer 35:687, 1975

14) Lewis JW, David LW, Lois JM, Sarah L: Lymphocyte subset in lung cancer. Chest 91:725, 1987

15) Tsuyugushi I, Shiratsuchi J, Fukuda M: Increased circulating activated T-cells in lung cancer. Chest 89:705, 1986

16) Cameron DJ, Churchill WH: Cytotoxicity of human macrophages for tumor cell. J Clin Invest 66:977, 1979

17) 박해심, 손희영, 이 훈, 안철민, 김성규, 이원영, 김 기호 : 폐암환자의 말초 혈액내 $\mathrm{T}$ 임파구아형 및 면역 반응. 대한내과학회지 $31: 148,1986$

18) 송재화, 이복희 : 각종 악성종양에서의 세포면역 기능 에 대한 연구. 충남의대잡지 $14: 210,1987$

19) Krant MJ, Manskopf G, Brandrup CS, Madoff MA: Immunologic alterations in bronchogenic cancer. Cancer 21:623, 1968

20) Cupissol D, Dabouis G, Decroix G: Delayed cutaneous hypersensitivity reactions in cancer patients by multitest. Med Oncol Abstr 118:30, 1979 